\title{
THE CONSTRUCTION OF HISTORY LEARNING ORIENTED TO GENDER EQUALITY
}

\author{
Yasmin Nindya Chaerunissa \\ Department of International Relations, Parahyangan Catholic University \\ yasminnch@gmail.com
}

Abstract:

Abstrak:

Gender issues have become a global agenda nowadays, where the inequality can make one of the parties, which in this case is women, discredited. Education, included history education of course, should be as one of the agents that can contribute to solve of gender problems. Based on social reconstruction philosophy, history education does not only talk about the past, but also relate to the present, and see the future. In this context, the history learning is made to be oriented in gender equality. The research location is on SMA Negeri 5 Bandung, class of social science. There are three main results in this research. First, to create a history learning that oriented to gender equality, the most important thing is that the teacher should have a deep understanding about it. It is fine whether the teacher is a man or woman, because gender equality is not only for woman, but for making a more equitable social order. History learning which oriented on gender equality could be delivered by its process and content. Second, on its implementation, history learning that could accommodate gender equality's values is contextual learning. Teacher should be clever enough to make connection between the past and the present. It should be done dialogically. Discussion might be made through question and answer which bridged with gender issues emancipatory critical questions. It could help the students shape their own thought and direct which values that suit into them. Third, through this kind of construction, it resulted that students' perception about gender equality developed. The students placed basically man and woman is in an equal partnership, where any kind of chances are open equally for both. It happened also friction about domestic role is not only for woman again, but as shared responsibility. Concluded, history learning could contribute in cultivating of gender equality, as a part to develop the social justice.

Isu gender telah menjadi agenda global saat ini, di mana ketidaksetaraan dapat membuat salah satu pihak, yang dalam hal ini adalah perempuan, didiskreditkan. Pendidikan, termasuk pendidikan sejarah tentu saja, harus menjadi salah satu agen yang dapat berkontribusi dalam memecahkan masalah gender. Berdasarkan filosofi rekonstruksi sosial, pendidikan sejarah tidak hanya berbicara tentang masa lalu, tapi juga berhubungan dengan saat ini, dan melihat masa depan. Dalam konteks ini, pembelajaran sejarah dibuat berorientasi pada kesetaraan jender. Lokasi penelitiannya adalah di SMA Negeri 5 Bandung, kelas ilmu sosial. Ada tiga hasil utama dalam penelitian ini. Pertama, untuk menciptakan pembelajaran sejarah yang berorientasi pada kesetaraan gender, yang terpenting adalah guru harus memiliki pemahaman mendalam tentang hal tersebut. Tidak masalah apakah gurunya laki-laki atau perempuan, karena kesetaraan jender tidak hanya untuk wanita, tapi juga untuk membuat tatanan sosial yang lebih adil. Pembelajaran sejarah yang berorientasi pada kesetaraan jender dapat disampaikan melalui proses dan isinya. Kedua, dalam implementasinya, pembelajaran sejarah yang bisa mengakomodasi nilai kesetaraan jender adalah pembelajaran kontekstual. Guru harus cukup pintar untuk membuat hubungan antara masa lalu dan masa kini. Ini harus dilakukan secara dialogis. Pembahasan bisa dilakukan melalui tanya jawab yang menjembatani isu gender dengan mengajukan pertanyaan kritis emansipatoris. Ini bisa membantu siswa membentuk pemikiran mereka sendiri dan mengarahkan nilai mana yang sesuai dengan mereka. Ketiga, melalui konstruksi semacam ini, hal ini mengakibatkan persepsi siswa tentang kesetaraan gender berkembang. Para siswa yang ditempatkan pada dasarnya pria dan wanita berada dalam kemitraan yang setara, di mana ada kemungkinan terbuka untuk keduanya. Itu terjadi juga gesekan tentang peran rumah tangga bukan hanya untuk wanita lagi, tapi sebagai tanggung jawab bersama. Disimpulkan, pembelajaran sejarah dapat berkontribusi dalam menumbuhkan kesetaraan jender, sebagai bagian untuk mengembangkan keadilan sosial.

Kata Kunci: $\quad$ social reconstruction, gender equality, dialogical learning 


\section{INTRODUCTION}

Gender issues are seen as something that needs to be highlighted, since there has been an imbalance in the society regarding the issues. Women have less access and opportunity than the men do. There are sentiments of its own related to the role of women in society. The emergence of the reformation era has signaled a change in the social domain, including gender equality in Indonesia (Blackburn, 2004, p. 1), yet it does not mean that gender equality has actually materialized. Despite women have started to have a chance to perform and play an important role in the public sphere in daily life, it is not a common thing culturally. It is closely related to the patriarchy culture that is inherent in Indonesia; the tendency to depict the superiority of men over women, which all social structures and practices in society are always more dominated by men as well as for the benefit of men themselves. Women are becoming the diminished and there is a perspective stating that women had better stay at home, no need high education, and many more. Men feel able to do anything against women, including violence. No wonder why de Beauvoir wrote a book entitled The Second Sex (1989) to portray the state of this subordination. Observed from the side of humanity, should not a group marginalize another group.

Saha (2011, p. 301) suggests that education is a process of socialization organized to prepare the citizens towards the goals. Education should be adjusted to the community framework. The underlying philosophy of education is the philosophy of social reconstruction. This philosophy of education is oriented to the present and the future (Hasan, 2012, p. 5). It means that education should be the contributing factor to meeting the community needs.

In the context of gender, education process in schools will exhibit a model of understanding of gender in society. Examined from the fundamental of social reconstruction associated with the character needs that ought to be owned, education presents to disseminate the values of gender equality to the learners. Wood (1994, p. 221) states that one of the educational solutions to give contribution to alleviate the gender issues is to improve the sensitivity of gender issues on the content and the learning process.

History education in schools, as part of education in general, of course, must be analogous with the philosophy of social reconstruction. The history learning oriented to gender equality itself is history learning that builds awareness of gender equality. History learning, both the content and strategy process, will develop a framework that men and women have equal opportunity of social role, and fulfillment of the rights that should be balanced as a human being (Saputra, 2007, p. 54).

There are no specific and direct materials on history learning in schools focused on the struggle for gender or women's history. History, nevertheless, with its vast scope, must have a track record regarding the struggle of gender in social life in the ancient times. If it is explored further, we will find the values that can inspire and support the creation of awareness related to gender equality, which can then be internalized into the students to address the social issues related to gender in the present. In order to make history learning contain more about the role of the person who is considered 'ordinary'-which in this context is the role of women $\neg$-and in order to make it more oriented to contemporary social issues, it is necessary to add a number of enriched small narratives (Supriatna, 2011, p. 23). Therefore, the content of the role of women in history can be featured. In addition, the bridge to connect the case in the past with the present is the analytical concept (Supriatna, 2012; p. 126), and critical questions to create a dialogical learning.

In this study, the values of gender equality must be adapted to the learning without losing the main basic concept of gender equality itself. Based on studies of gender and equality that has been described previously, researcher compiled three main points that are used as indicators or core values of gender equality in history learning. The key values of gender equality in history learning is the equal partners relations of men and women, the balanced opportunity in participate, and avoidance of stereotypes.

\section{RESEARCH METHOD}

This research was executed with qualitative research design. A qualitative research design is an approach for exploring and understanding the meaning individuals or groups ascribe to a social or human problem (Creswell, 2012, p. 4). The significance that is about to be understood in the context of this research is the study of history oriented to gender issue itself.

The method applied in this research is naturalistic inquiry method. This method calls for facts as an integrity that cannot be understood if they are separated from its context. The observation in this study affects what is seen. Therefore, this research must take place on the unity in the context for understanding purposes. In addition, the context is also crucial in determining whether a discovery has another context meaning, which means that a phenomenon should be viewed in its entirety in the field (Lincoln \& Guba, 1985, p. 39).

Researcher regarded the naturalistic inquiry method as a method that has accordance with the question in this study for several reasons. The main reason that underlied most was naturalistic-inquiry as a qualitative research aims to comprehend the phenomenon of what is experienced by research subjects holistically (Moleong, 2011, p. 6). This is similar to researcher's goal, in which researcher attempted to capture the idea of the history teachers who implemented the history learning that led to the orientation of gender equality as well as in viewpoint of the students that was gained from the learning outcomes. As previously mentioned, whatever was in the field would be captured as it was. Another reason was this study focused on the implementation process of history learning oriented to gender equality. An implementation process should be apprehended with intact, so that researcher had a clear picture of the events that were taking place.

The study was conducted during the months of January to May 2015 at SMAN 5 Bandung. The research location 
was determined based on the principle of typical cases. This school has a learning system that starts to lead to gender equality. In the content of subject history, the material is not so different from other schools. However, the interesting part here is how teachers can mention the role of women in history to explore students' minds and direct the learning process on understanding the values of gender equality. Here, with the inclusion of the historical narratives of women and nondescriptive learning, history learning can be referred towards gender equality.

In this research, researcher had a partner teacher named Eka Harijanto. Partner teachers acted as a material-serving teacher in the classroom. Meanwhile, researcher took role as an observer in the classroom. Researcher kept track of anything that happened in the classroom and then collected data to be analyzed in accordance with the indicators that had been made. Researcher's role as an observer was notable and could not be replaced by anyone, since researcher was the only one who knew the intricacies and detail information required in the study. This was closely related to researcher as the research instrument.

\section{RESULTS}

The results of this study are divided into three components. First, the discussion about the values of gender equality can be accommodated in history learning conducted at research sites examined by me as the researcher, including partner teachers' paradigm in understanding concept of gender and regarding gender equality. Second, a review of the implementation of the history learning oriented to gender equality. Third, the results of the study that has been done regarding the history learning oriented to gender equality.

\section{Values accommodation of gender equality in history learning}

\section{a. Partner teachers' perception}

From the interview results conducted for partner teachers, it can be said that they have a good understanding of gender or gender equality. It can be seen from their answers when asked about gender, they replied that gender is a distinction of the roles between men and women, yet is based on the culture. The next question, researcher asked about the value of equality between men and women. Responding to this question, the teachers explained that men and women should have equal position by rights. No one is superior to the other. If the position of men and women is equal, should there not be any discrimination to achieve something just because someone is male or female.

Nevertheless, partner teachers admitted that realizing a harmonious relation between men and women has obstacles to overcome. One of them, and is the most dominant, is culture. There are, indeed, cultures that are placing men on the higher positions, or discriminate against women. Afterwards, this patriarchal culture produces certain stereotypes related to women and often become detrimental.
In order to make gender equality accepted in society, one of the factors that determines is the level of education. A good education tends to make people have an open mindset, so that a socialization needs to be conducted through education itself. Partner teachers stated that education at schools should not only teach the materials, but also embed soft skills related to social values, including the values of gender equality. Such learning can be delivered with hidden curriculum. Hidden curriculum can be perceived as an unwritten goal (hidden), but its accomplishment needs to be considered by the teacher, so that the learning quality is much more meaningful (Sanjaya, 2009, p. 26).

The thought of the partner teacher who has understood the values of gender equality seems to be interesting since he is a man. Gender equality is not just talking about and discussed by women only, but since women are often aggrieved, the concept of gender equality fought by feminism are held by women more. There is certainly no something wrong if a man can think egalitarian about gender, more than that, this is a positive thing. Back to Gandhi's quotes (2001, p. xix), men who enjoyed access in public spaces should be able to make space for women. In the context of education, this could be an attempt of planting awareness of gender equality for justice. It should be noted that feminism strives to eliminate the causes of inequality and seeks ways that men and women can have equal opportunities in all areas according to their potential. Therefore, feminism is not just the struggle owned only by women.

\section{b. Accommodation framework of gender equality values in history learning}

The partner teacher emphasizes that in spite of the teachers' competence in looking for relevance, not all topics in learning history can be infiltrated by all kinds of social issues. The topic of history, contemporary social issues, and values that will be brought into the lessons should be compatible. Similarly, the value of gender equality, the linkage between learning and gender issues considered properly. This needs to be maintained, so that the teaching of history itself remains on the corridor. In bringing the contextual history aching, partner teachers should stand for the fundamental aspects of history itself, so that they will not leave the historical context of the learning process itself just because they are too busy to talk about social issues nowadays.

To be able to make the material role of women in history convey the values of gender, we cannot only deliver it descriptively. The explanation of the teacher is of course required to establish the historical framework in the scheme of students' thinking, which begins with the historical material in general in accordance with the curriculum and then swoops to the material related to women. Having alluded to the material of women in history, learning can then be followed by a discussion related to gender issues. This discussion begins with teachers asking critical questions. Partner teachers emphasize that the discussion does not only invite the students 
to argue, but the teacher can also steer the discussion, so that the expected values, in this context the value of gender equality, can be accommodated. Another addition is that the conclusions of the teacher occupies an important position, as the conclusion of the teacher will give the students a kind of strengthened justification related to the values of gender equality that are embedded.

\section{The implementation of history learning oriented to gender equality}

During the research, partner teacher tried to link the values of gender equality to three main topics, namely the French Revolution, the Russian Revolution, and the Indonesian National Movement. The detailed explanation of the implementation can be seen in Table 1 .

As already mentioned that the teaching of history oriented to gender equality is based on the philosophy of social reconstruction. The philosophy of social reconstruction believes that schools can reflect the dominant social values and should be a source of social innovation; and the teacher is the instrument, activator, and the main agitator of change and enlightenment of the social issues (Knight, 2009, pp. 187188). Partner teacher who already has a very clear function as a manager, facilitator, and filter has performed the tasks very well.

Relooking at the data in the syntax of learning implementation in the Table 1, the learning that is made to expand students' point of view not only in discussions, but in also making solutions, and then to steer students on the conclusions of gender equality. This is consistent with the underlying philosophy of social reconstruction. As Knight stated (2009, p. 188) that education based on the philosophy of social reconstruction, which discusses social issues--in which gender equality issues included in it--should be done with the teaching method that is based on democratic principles, reflecting on the problem and offering solutions.

History learning that was brought by partner teacher always emphasized the historical content at first. Obviously, this is carried out in order to generalize the lesson. Convincing self that students have understood the content of history is important for the partner teacher. If the students have understood the concepts in the content, the partner teacher will easily invite students to discuss the lesson. It is like what is disclosed by Lee (2005, p. 73), that learners need a strong foundation of knowledge of the disciplines studied.

The lessons brought by partner teacher can also be classified as a Contextual Teaching and Learning (CTL). Johnson (2002, p. Vii) reveals that there are two important things that have to be connected when bringing contextual learning, namely linking the lesson content and context of students' daily lives. The term of the lesson that tried to link the social issues in the society with the topics learned in class in this way can also borrow terms from Evans \& Brodkey (1996, p. 254) called issue-centered curriculum. Linking what is learnt in school to the real world makes the lesson applicable. Therefore, the teaching of history becomes flexible. When studying the history becomes reflection media of daily life, the history lessons can be very beneficial for students. Things that are linked by partner teachers as listed in Table 1 are already clearly visible. Glimpses of various lessons' materials associated with gender, partner teacher can already deliver things like avoiding the stereotypes of women, discussing the role of women in government, mentioning women's role in the field of work, and the contribution of women in the formation of the nation-state of Indonesia. In addition, the students were invited to perform a comparative study of the condition of women in the past with these days.

Table 1

Syntax of History Learning Implementation Oriented in Gender Equality

\begin{tabular}{|l|l|l|l|l|}
\hline \hline No & \multicolumn{1}{|c|}{ STEPS } & \multicolumn{3}{|c|}{ DESCRIPTION } \\
\hline 1 & Determining topic & French Revolution & Russian Revolution & Indonesian National Movement \\
\hline 2 & $\begin{array}{l}\text { Exploring the material } \\
\text { in order to link the } \\
\text { issues and values of } \\
\text { gender }\end{array}$ & $\begin{array}{l}\text { One of the backgrounds of } \\
\text { France Revolution is crisis in } \\
\text { economic, and the situation } \\
\text { getting worse with Marie } \\
\text { Antoinette's behavior who liked to } \\
\text { dissipate. } \\
\text { Relation: }\end{array}$ & $\begin{array}{l}\text { Progressive economic style in } \\
\text { Russia repressed labors with low } \\
\text { salary payment. Moreover, there was } \\
\text { differentiation between women and } \\
\text { men labors salary. } \\
\text { Relation: woman labors } \\
\text { condition. }\end{array}$ & $\begin{array}{l}\text { Indonesian National } \\
\text { politics, but also conductors in } \\
\text { social-cultural aspect including } \\
\text { women movement. } \\
\text { Relation: Both men and } \\
\text { women had positive contribution } \\
\text { in Indonesian National } \\
\text { to dissipate, position of woman in } \\
\text { government }\end{array}$ \\
& & $\begin{array}{l}\text { Background and process of } \\
\text { French Revolution. }\end{array}$ & Background of Russian Revolution & $\begin{array}{l}\text { Types of organization } \\
\text { contributed in Indonesian } \\
\text { National Movement }\end{array}$ \\
\hline 3 & Explaining & & & \\
\hline
\end{tabular}




\begin{tabular}{|c|c|c|c|c|}
\hline 4 & $\begin{array}{l}\text { Rising critical } \\
\text { question }\end{array}$ & $\begin{array}{l}\text { Written questions: } \\
\text { a. In your opinion, was Marie } \\
\text { Antoinette's behavior in } \\
\text { dissipating adequate as the } \\
\text { woman who always stayed } \\
\text { at palace? } \\
\text { b. If Marie Antoinette had had } \\
\text { intellectual capacity, in your } \\
\text { opinion, should she become } \\
\text { a queen who stayed in the } \\
\text { palace or reigned the French } \\
\text { government? } \\
\text { c. Must a kingdom or a } \\
\text { country be led by a king } \\
\text { or man? Do women have } \\
\text { opportunity to reign a } \\
\text { kingdom or a country also? }\end{array}$ & $\begin{array}{l}\text { Written questions: } \\
\text { a. Russian labors salary was very } \\
\text { low, moreover woman labors } \\
\text { salary was even lower than } \\
\text { man labors. What do you } \\
\text { think about this situation? } \\
\text { b. If that situation happens in } \\
\text { Indonesia right now, what } \\
\text { kind of solutions you can do? }\end{array}$ & $\begin{array}{l}\text { Oral questions: } \\
\text { a. Why is women movement } \\
\text { important in Indonesian } \\
\text { National Movement era? } \\
\text { b. What was the contribution } \\
\text { of women movement } \\
\text { in Indonesian National } \\
\text { Movement era? } \\
\text { Written questions: } \\
\text { c. In your opinion, based on } \\
\text { today's situation, is women } \\
\text { movement still relevant or } \\
\text { needed? Why? } \\
\text { d. 1)If needed: What kind } \\
\text { of way can we do the } \\
\text { movement? } \\
\text { 2) If not needed: Does it } \\
\text { mean no discrimination } \\
\text { according to women role } \\
\text { anymore? So, how can } \\
\text { we maintain this positive } \\
\text { situation? } \\
\text { e. What kind of positive } \\
\text { values which can you gain } \\
\text { from Kartini's and Sartika's } \\
\text { struggle? Why do you } \\
\text { those are positive? }\end{array}$ \\
\hline 5 & Making discussion & Teacher as facilitator & Teacher as facilitator & Teacher as facilitator \\
\hline 6 & Concluding & $\begin{array}{l}\text { Teacher filtered and gave } \\
\text { conclusion. }\end{array}$ & $\begin{array}{l}\text { Teacher filtered and gave } \\
\text { conclusion. }\end{array}$ & $\begin{array}{l}\text { Teacher filtered and gave } \\
\text { conclusion, several point had } \\
\text { not discussed yet according to } \\
\text { time limit. }\end{array}$ \\
\hline
\end{tabular}

This dialogical learning cannot be separated from the critical questions related to the values of gender equality that can be extracted from students' daily thoughts. Critical questions that are widely used by teachers are emancipatory critical and hypothetical questions. Brooks \& Brooks (1999, p. 108) argue it can assist learners in the formation of meaning for themselves. It can be said that an emancipatory question is a question that asks why something should happen as has already happened (Kemmis \& Fitzclarence, in Supriatna, 2007, p. 120-121). It means there are some 'lawsuit' questions towards what has happened. These questions include questions that invite students' arguments to assess something that has happened. It also contains what should have done then and now. Meanwhile, a hypothetical question is a conditional question, which is usually called as if history.

Table 2

Discussion of woman labors salary, related to Russian Revolution

Teacher : $\quad$ "In Russia, there was differentiation between women and men labors salary. Basically, Russian labors salary was very low; moreover woman labors salary was even lower than man labors. What do you think about this situation? Yes, please, Dhyaa Bintang."

Dhyaa Bintang: "That situation should not happen. The factory owner should not differentiate salary based on gender. If the workload was same, the salary should be same also. If they wanted to make woman labor lower than men labor, simply the workload had to be increased."

Teacher : " "Okay, very good. Hadi, don't you want to try? You used to deliver your argument," 


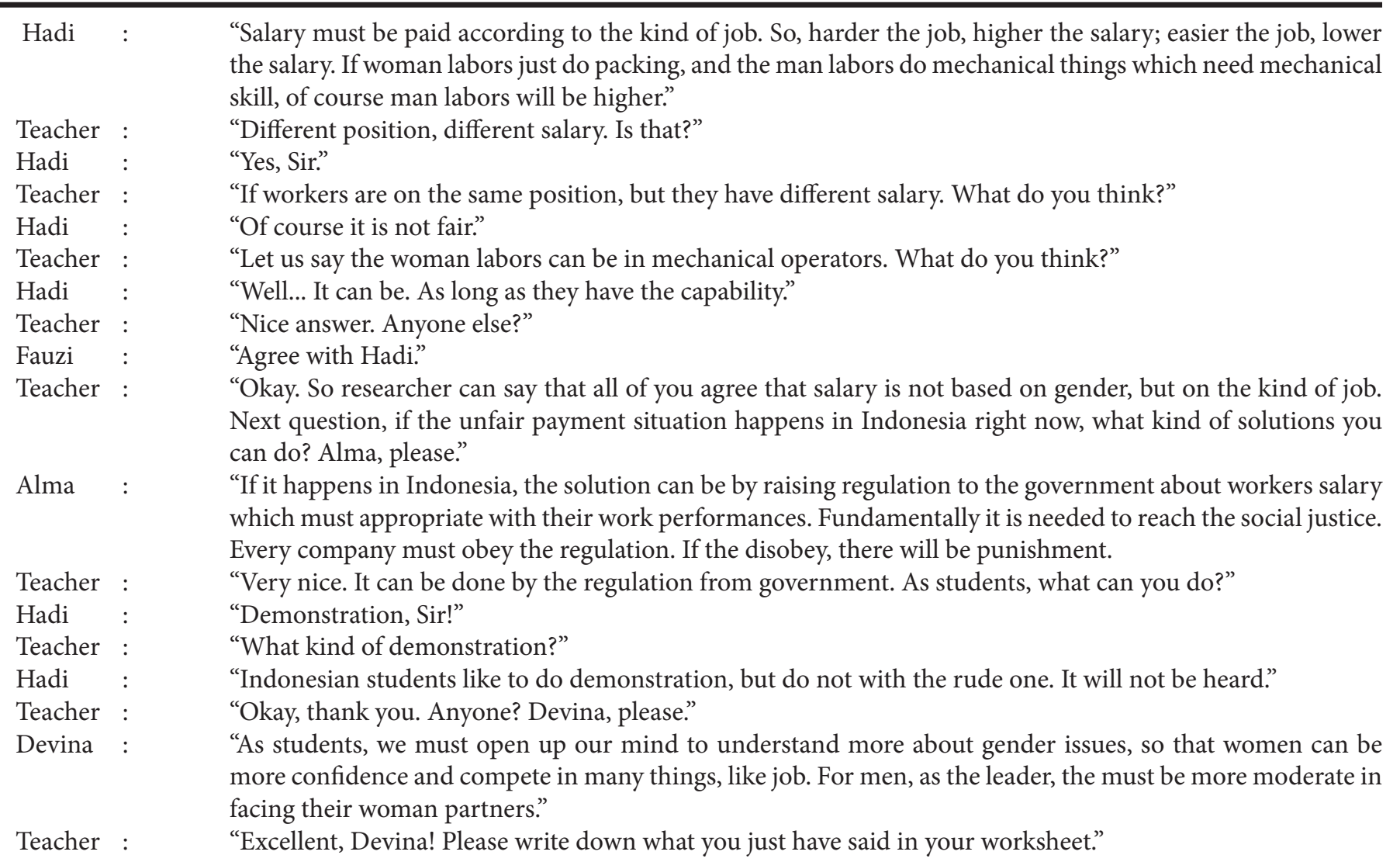

Teacher's behavior in the classroom is an important thing. Teachers may not be able to instill certain values to the students if he himself does not live by those values. Teachers must not educate a certain value only by verbal communication. A value can be, if it is held to be more than a mere verbal formulation. Horgan (1995, pp. 9-16) confirms that in order to avoid gender bias in learning, teachers should not differentiate his attitude to both boys and girls. Teachers who try to be too good to female students will increasingly reflect gender inequality. When students get in trouble, if the teacher acts nicer to girls than to boys, the teacher suggests that women do not have to struggle as hard as men do. Too much helping women means indirectly affirming that female students tend to be unable to or weaker than the male students are. Horgan addresses this educational phenomenon by killing girls with kindness.

In the learning process, the values of gender equality are shown by partner teachers by rewarding students with no views of whether he is male or female. Teachers appreciate students who excel and rebuke students who do not obey the rules. Any sanctions imposed in accordance with the breach. A firm and discipline partner teacher clearly seeks not to discriminate against the students. All the things demonstrated by the partner teacher showed that there were no superior male or female students, except from the behavior and ability of the students themselves. It means, fundamentally, partner teacher tries to take their position in an equal partner relationship. The opportunity to participate equally between boys and girls can be seen from the attitude of teachers who are not picky towards the students during the lesson.

\section{The outcomes of history learning oriented to gender equality}

Learning outcomes that are referred here is how students perceive the gender equality itself. In other words, the results that will be discussed here is more substantial in the meaning of gender equality during the lesson. The outcomes of the lesson are seen from the discussion, arguments presented by students through assignments, and the results of questionnaires filled out by students.

One of the hypothetical questions that can be said to be appealing in the topic of the French Revolution is 'If Marie Antoinette as a woman having an adequate intellectual ability, do you think she should be still the queen who resides in his palace or reign the kingdom of France?'. Dhyaa Bintang, Irestaluna, Naraya, Vania, Alma, Herda, Devina, and Maurizqa were those who argued that Marie Antoinette (female) should reign the kingdom of France. Alma and Herda emphasized that being queen is not just a matter of luxury, but it should have a role in building and organizing the country. Devina and Maurizqa write a more comprehensive case, they wrote,

Yes, first because she can be more helpful if she rules the kingdom. It could make her understand the conditions and wishes of the people, so that she can be busy, not squander, and are detrimental to the state. She also can be an inspiring woman in France, encourage emancipation, and tear down the stereotype that women are weak, can only stay at home, and many more. Her presence is necessary to substitute the reign of Louis XVI who was submissive and weak. 
Devina and Maurizqa criticized that by having contribution to her country, Marie Antoinette will be able to have other positive effects. They consider that to contribute, inspire, and show emancipation, it will remodel the existing stereotypes about women in society.

Moving on to another question, 'Should a kingdom or nation always be led by men, or can it be led by a woman?'. All students argued that either men or women could lead a kingdom or country. However, some students wrote particular notes. For example, men would take precedence.

Two other students, Cynthia and Nadia, compared men and women by stereotype instead. They mentioned,

...but in terms of leadership character, a man (king) are preferred as the leader since they use logic to the top, so that they can create an adequate strategy compared to a female (queen).

There was consistent answer of the values of gender equality from the eight other students. Dhyaa Bintang, Irestaluna, Naraya, and Vania said that the most important thing to be a leader is the ability, not gender. Alma and Herda argued similarly, no matter whether she has reliable constitutional ability, the country will advance.

Devina and Maurizqa apparently realized better on this question than his friends did. They thought it is possible for women to lead a kingdom or state. However, a state that has been embedded, like a rule, makes women do not have a chance to be a leader.

Researcher tried to compare the responses of the students at the beginning of the semester with the result that researcher obtained through questionnaires at the end of the semester. $33 \%$ of respondents agreed and 52\% disagreed on the point number 5, namely that men or women might lead if they could. Meanwhile, 7\% stated they strongly disagreed, and other $7 \%$ disagreed. In the next statement, the one with 'it does not matter if it is led by a woman as long as she can' was approved by $30 \%$ of students and highly approved by $48 \%$ of students. The rest, $11 \%$ felt troubled if led by women, and $11 \%$ were very problematic if led by women, even though women were capable.

It can be concluded that, most of them did not mind who becomes a leader as long as they are able and not too problematic if women lead them. Nevertheless, in the process of determining these leaders, many of them still gave priority to men; however, if the result is women, in general it is acceptable to them. Here, the perception of the opportunity to participate is not fully balanced.

Seen from the perspective of feminism in functionalism analysis, it can be studied from the analysis of liberal feminism. According to this theory, the one of backwardness of women is women do not participate in the establishment. Therefore, involving women in industrialization and development program is considered as a way to improve the status of women (Fakih, 103, p. 83). However, before they can contribute, an equal opportunity and equal rights for every individual are required, including for women. Then, the thing that is requested here is the equal opportunity to contribute. It does not mean that women should be like men, but they have an equal opportunity. The case whether women or men are able to compete is a different matter. Going back to the students' answers, by giving contribution, women have a new image in the community.

On learning about the Indonesian National Movement, in which discussed about the women's movement, the teacher discussed the urgency of the women's movement for the national movement. After that, the teacher associated it with the current situation in general and led learners to be able to find the solution to the problem of gender equality. The discussion began with the question 'Do you think, based on current conditions, whether is struggle to elevate women still needed/relevant? Why?' Of the 24 students who did the task that day, only 6 declaring unnecessary.

For those who agreed, the reason usually is that these days there are many women who are discriminated or underestimated. Cynthia and Nadia argued although they have now the same position, we still must keep on fighting the rights for women. Dhyaa Bintang and Irestaluna argued we could oppose the traditional stereotypes that exist. Interesting statement from Faldi and Verid, they considered the struggle for women's rights must still be fought for since there are still women who become prostitutes because of the pressures of life.

Learners were asked to provide solutions to many problems that occurred in the issue of gender equality. Many of them wrote that the main solution was through education and socialization. This matches the statement of Wood (1994, p. 221), "Four particular means to ending discrimination are equal opportunity, affirmative action, quotas and goals, and increasing sensitivity to gender issues in educational content and processes." Even to protect it all, the thing that is required is the state's role in making and enforcing laws related to this issue. As expressed by Friedan (1963) who thinks that the government, through their policies, must be able to resolve the problems of women who have weak position as citizens.

Most students also explained that the solution to respond the problem of gender inequality is to start from ourselves, such as not to be labeled so far by the existing stereotypes. They believed a woman should not be weak, does not be afraid of men if they act properly, and many more. researcher assess there has been a growing awareness of the student that if you want to create an egalitarian social conditions, then do not cripple the condition and let it imbalanced. Such students have consciously determined their existence. They who are able to determine what value that is suitable for them are like existentialist feminism's point of view, namely the identity of a person obtained through the process selected by the individuals themselves consciously and it is not determined in advance by the society (Thornham, 2000, p. 46). Researcher would like to say that the successful history learning that helps students determine the value for themselves is a very meaningful learning.

For a more convincing result of this study, on the questionnaire researcher had given to the students, there are some points that can be used to strengthen the students' answers. 
Table 3 Questionnaire outcomes on students' perception towards gender equality after history learning

In the history learning, women's role was alluded several times. I realize that:

\begin{tabular}{|c|c|c|c|c|c|c|c|c|c|}
\hline \multirow[t]{2}{*}{ NO } & \multirow[t]{2}{*}{ STATEMENT } & \multicolumn{2}{|c|}{$\begin{array}{c}\text { VERY } \\
\text { DISAGREE }\end{array}$} & \multicolumn{2}{|c|}{ DISAGREE } & \multicolumn{2}{|c|}{ AGREE } & \multicolumn{2}{|c|}{$\begin{array}{c}\text { VERY } \\
\text { AGREE }\end{array}$} \\
\hline & & $\sum$ & $\%$ & $\sum$ & $\%$ & $\sum$ & $\%$ & $\sum$ & $\%$ \\
\hline 1 & $\begin{array}{l}\text { Man is not always in higher quality level than woman, because no kind } \\
\text { of gender is higher than the other }\end{array}$ & 1 & $4 \%$ & 2 & $7 \%$ & 10 & $37 \%$ & 14 & $52 \%$ \\
\hline 2 & $\begin{array}{l}\text { Man and woman must have balance opportunity in participating and } \\
\text { developing their potency }\end{array}$ & 2 & $7 \%$ & 0 & $0 \%$ & 4 & $15 \%$ & 21 & $78 \%$ \\
\hline 3 & Both man and woman contributed positively in history & 1 & $4 \%$ & 3 & $11 \%$ & 7 & $26 \%$ & 16 & $59 \%$ \\
\hline 4 & $\begin{array}{l}\text { The quality of man and woman depends on the individual capacity, not } \\
\text { because they are man or woman }\end{array}$ & 2 & $7 \%$ & 0 & $0 \%$ & 4 & $15 \%$ & 21 & $78 \%$ \\
\hline 5 & Man or woman can be leader, if they have capability & 2 & $7 \%$ & 2 & $7 \%$ & 9 & $33 \%$ & 14 & $52 \%$ \\
\hline 6 & Have no rejection to be led by woman & 3 & $11 \%$ & 3 & $11 \%$ & 8 & $30 \%$ & 13 & $48 \%$ \\
\hline
\end{tabular}

Table 4 Questionnaire Outcomes on Students' Perception towards Gender Equality In Daily Life

In daily life, I assume that:

\begin{tabular}{|c|c|c|c|c|c|c|c|c|c|}
\hline \multirow[t]{2}{*}{ NO } & \multirow[t]{2}{*}{ STATEMENT } & \multicolumn{2}{|c|}{$\begin{array}{l}\text { VERY } \\
\text { DISAGREE }\end{array}$} & \multicolumn{2}{|c|}{ DISAGREE } & \multicolumn{2}{|c|}{ AGREE } & \multicolumn{2}{|c|}{$\begin{array}{l}\text { VERY } \\
\text { AGREE }\end{array}$} \\
\hline & & $\Sigma$ & $\%$ & $\Sigma$ & $\%$ & $\Sigma$ & $\%$ & $\Sigma$ & $\%$ \\
\hline 7 & Salary is not decided by the gender, but by the working performance & 2 & $7 \%$ & 0 & $0 \%$ & 8 & $30 \%$ & 17 & $63 \%$ \\
\hline 8 & $\begin{array}{l}\text { Domestic violence (which victim usually are woman) is not appropriate } \\
\text { to be done }\end{array}$ & 2 & $7 \%$ & 3 & $11 \%$ & 5 & $19 \%$ & 17 & $63 \%$ \\
\hline 9 & $\begin{array}{l}\text { Domestic business, such as housekeeping, is a mutual responsibility, } \\
\text { both man and woman }\end{array}$ & 1 & $4 \%$ & 2 & $7 \%$ & 5 & $19 \%$ & 19 & $70 \%$ \\
\hline 10 & Man and woman must cooperate for making social justice in life & 2 & $7 \%$ & 0 & $0 \%$ & 4 & $15 \%$ & 21 & $78 \%$ \\
\hline 11 & Education is the most important thing for everybody & 2 & $7 \%$ & 0 & $0 \%$ & 2 & $7 \%$ & 23 & $85 \%$ \\
\hline 12 & Clever mothers will have clever children & 3 & $11 \%$ & 7 & $26 \%$ & 6 & $22 \%$ & 11 & $41 \%$ \\
\hline 13 & $\begin{array}{l}\text { Even later will be a housewife, woman must have a high quality } \\
\text { education }\end{array}$ & 3 & $11 \%$ & 1 & $4 \%$ & 5 & $19 \%$ & 18 & $67 \%$ \\
\hline 14 & $\begin{array}{l}\text { For man: want to have a smart wife } \\
\text { For woman: want to be a smart woman }\end{array}$ & 2 & $7 \%$ & 0 & $0 \%$ & 6 & $22 \%$ & 19 & $70 \%$ \\
\hline
\end{tabular}

Table 5 Questionnaire outcomes on students' perception towards gender equality in daily life

\begin{tabular}{|c|c|c|c|c|c|c|c|c|c|}
\hline \multirow[t]{2}{*}{ NO } & \multirow[t]{2}{*}{ STATEMENT } & \multicolumn{2}{|c|}{$\begin{array}{l}\text { VERY } \\
\text { DISAGREE }\end{array}$} & \multicolumn{2}{|c|}{ DISAGREE } & \multicolumn{2}{|c|}{ AGREE } & \multicolumn{2}{|c|}{$\begin{array}{c}\text { VERY } \\
\text { AGREE }\end{array}$} \\
\hline & & $\Sigma$ & $\%$ & $\sum$ & $\%$ & $\Sigma$ & $\%$ & $\Sigma$ & $\%$ \\
\hline 15 & Man uses logic in doing something & 1 & $4 \%$ & 3 & $11 \%$ & 0 & $37 \%$ & 12 & $44 \%$ \\
\hline 16 & Woman uses feeling in doing something & 2 & $7 \%$ & 3 & $11 \%$ & 3 & $48 \%$ & 8 & $30 \%$ \\
\hline 17 & $\begin{array}{l}\text { Man is more suited to menial jobs (e.g. repair vehicles, working in the } \\
\text { mining domain) }\end{array}$ & 1 & $4 \%$ & 3 & $11 \%$ & 1 & $41 \%$ & 9 & $33 \%$ \\
\hline 18 & $\begin{array}{l}\text { Woman is most suited to soft jobs (e.g. sewing, cleaning, working as a } \\
\text { nurse) }\end{array}$ & 1 & $4 \%$ & 9 & $33 \%$ & 9 & $33 \%$ & 8 & $30 \%$ \\
\hline 19 & The things outside house are fully man's responsibility (working, driving) & 5 & $19 \%$ & 10 & $37 \%$ & 9 & $33 \%$ & 3 & $11 \%$ \\
\hline 20 & $\begin{array}{l}\text { The things inside house are fully man's responsibility (cleaning, cooking, } \\
\text { raising children) }\end{array}$ & 6 & $22 \%$ & 12 & $44 \%$ & 6 & $22 \%$ & 3 & $11 \%$ \\
\hline
\end{tabular}


The stereotype that still lingers is about men who act based on logic, while women act based on feelings. This is reflected in the responses of students, both orally and in writing. researcher assume that it has something to do with the stereotype that women should appear gentle and are more suited to the realm of a light job. Wollstonecraft sees this happens because of the socialization process in which women are encouraged to act in a feminine attitude (Sapiro, 2005, p. 424). Researcher also notices the condition of the existing sociocultural perpetuates this case, regardless of whether the biological effect contributes or not. Women are always brought near to the mild stuff since long time ago, given bright colors, play cooking, playing salon, et cetera. The environment is also responsible for this. It means this is all happening because it has been accustomed. If women are taught to be independent since they are children, they will have a firm figure in the future.

\section{CONCLUSION}

The more understanding and awareness about gender equality that the teacher has, the more values of gender equality can be accommodated in history learning. A history teacher will not possible cultivate gender equality values in students if he or she does not live with the values itself. History learning which can accommodate gender equality values is contextual history learning. Not only describing and explaining past events descriptively, but also relating it with contemporary things contained gender issues. In the implementation, to stimulate students' awareness in gender equality, it is strongly recommended to create history learning not in one way learning, nevertheless in dialogical learning. Through discussion bridged by critical questions contained gender issues, students will be induced to open their minds. Moreover, teacher who delivers well the history learning contained gender issues can carry the students to find right solutions for

contemporary gender problems. It is definitely, as one of the socialization agents to create gender equality awareness; history learning can be classified as a meaningful learning.

\section{REFERENCES}

Abdullah, T. 2001. Nasionalisme \& sejarah. Bandung: Satya Historika.

Abdullah,T (ed.). 2010. Sejarah lokal di Indonesia. Yogyakarta: Gadjah Mada University Press.

Blackburn, S. 2004. Women and the state in modern Indonesia. Cambridge: Cambridge University Press.

Brooks \& Brooks. 1999. In search of understanding: The case for constructivistic classrooms. Virginia: ASCD.

Buchori, M. 1995. Transformasi pendidikan. Jakarta: Pustaka Sinar Harapan.

Bungin, B. 2003. Analisis data penelitian kualitatif. Jakarta: Rajagrafindo Persada

Creswell, J.W. 2012. Research design: Pendekatan kualitatif, kuantitatif, dan mixed. Yogyakarta: Pustaka Pelajar. de Beauvoir, S. 1989. The second sex. New York: Vintage Book.

Evans, R.W. \& Brodkey, J. 1996. An issues-centered curriculum for high school social studies. Dalam R.W. Evans \& D.W. Saxe, Handbook of teaching social studies (hlm. 254-264). Washington: National Council for the Social Studies.

Fakih, M. 2013. Analisis gender dan transformasi sosial. Yogyakarta: Pustaka Pelajar.

Gandhi, L. 2001. Teori poskolonial: Upaya meruntuhkan hegemoni barat. Yogyakarta: Qalam.

Hasan, S.H. 2012. Filosofi dan peran pendidikan sejarah untuk membangun karakter bangsa. Dalam S.H. Hasan, Pendidikan sejarah Indonesia: Isu dalam ide dan pembelajaran (hlm. 1-16). Bandung: Rizqi Press.

Horgan, D.D. 1995. Achieving gender equity: Strategies for the classroom. Massachusetts: Allyn and Bacon.

Jarolimek, J. 1986. Social studies in elementary education. New York: Macmillan Publishing Company.

Johnson, E.B. 2002. Contextual teaching and learning: What it is and why it's here to stay. California: Corwin Press.

Knight, G.R. 2009. Filsafat pendidikan. Yogyakarta: Gama Media.

Kochhar, S K 2008. Pembelajaran Sejarah, Teaching of History. Jakarta: Gramedia.

Lee, P.J. 2005. Putting into practice: Understanding history. Dalam M.S. Donovan \& J.D. Bransford (Penyunting), How students learn history in the classroom (hlm. 31-78). Washington DC: The National Academy Press.

Lincoln, Y.S. \& Guba, E.G. 1985. Naturalistic-inquiry. London: SAGE Publications.

Miles, M.B \& Huberman, A.M. 1992. Analisis data kuantitatif, metoda-metoda baru, (terjemahan oleh Tjetjep Rohendi Rohidi). Jakarta: UI Press.

Moleong, L.J. 2011. Metodologi penelitian kualitatif. Bandung: PT Remaja Rosdakarya.

Saha, L.J. 2011. Sociology of education. Dalam T.L. Good, 21st century education: A reference handbook (hlm. 299-307). London: SAGE Publications.

Sanjaya, W. 2008. Kurikulum dan pembelajaran: Teori dan praktik pengembangan kurikulum tingkat satuan pendidikan. Jakarta: Kencana Prenada Media Group.

Sapiro, V. 2005. Subjek yang sama berlanjut. Dalam J. Losco \& L. Williams, Political Theory: Kajian klasik dan konteporer (hlm. 417-442). Jakarta: PT Raja Grafindo Persada.

Saputra, Wr.H. 2007. Pendidikan berperspektif gender di Indonesia. Historia. Journal of Historical Studies, 8, (1), hlm. 45-60.

Supriatna, N. 2007. Desain pembelajaran sejarah yang berorientasi pada masalah-masalah sosial kontemporer. Dalam N. Supriatna (Penyunting), Konstruksi pembelajaran sejarah kritis (hlm. 117-128). Bandung: Historia Utama Press.

Supriatna, N. 2011. Konstruksi pembelajaran sejarah yang berorientasi pada masalah kontemporer pembangunan. Mimbar. Jurnal Sosial dan Pembangunan, 27, (1), hlm. 21-30. 
Supriatna, N. 2012. Pengunaan konsep ilmu sosial dalam konstruksi pembelajaran sejarah kritis. Paramita. Jurnal Sejarah dan Pembelajaran Sejarah, 22, (1), hlm. 122-130.

Thornham, S. 2000. Teori feminis dan cultural studies: Tentang relasi yang belum terselesaikan. Yogyakarya: Jalasutra.

Widja, I Gde. 1991. Sejarah lokal suatu perspektif dalam pengajaran sejarah. Bandung: Angkasa
Wineberg, Sam 2006. Berfikir historis, memetakan masa depan mengajarkan masa lalu. Jakarta: Yayasan Obor Indonesia Wood, J.T. 1994. Gendered lives: Communication, gender, and culture. California: Wadsworth. 